\title{
STaaS Xidmətləri və Viki-layihələr: Oxşar və Fərqli Cohətləri
}

\author{
İradə Oləkbərova \\ AMEA-nınİnformasiya Texnologiyaları İnstitutu, Bakı, Azərbaycan \\ airada.09@gmail.com
}

\begin{abstract}
Xülasə- Məqalədə bulud xidmətlərinin xüsusiyyətləri analiz edilmiş, bulud saxlamaları ilə viki konsepsiyasının işləmə prinsipləri müqayisə olunmuşdur. Bulud xidmətləri ilə vikilayihələrin oxşar və fərqli xüsusiyyətləri müəyyənləşdirilmişdir.
\end{abstract}

Açar sözlor- viki texnologiyaları, bulud xidmotlori, bulud saxlamaları, ictimai bulud, multi-icaro, proqram platformaları

\section{GiRİş}

Cəmiyyətdəki yeni sosial münasibətlər, müasir informasiya texnologiyalarını (İT) dəstəkləyən informasiya mədəniyyəti və gündən-günə genişlənən informasiya bolluğu qlobal informasiya məkanı formalaşdırmaqdadır. Müasir İnternettexnologiyalar vətəndaşların təcrübə və biliklərinin artırılmasında, davranışlarında, müstəqil təhsildə, müxtəlif təyinatlı informasiya resurslarından düzgün istifadə üçün lazımi biliklərə yiyələnməkdə mühüm əhəmiyyət kəsb edir. İformasiyanın səmərəli istifadəsi prosesində vaxta, aparat və proqram təminatına qənaət, əlavə xərclərdən azad olmaq kimi məsələlər ön plana keçir. Son illər belə məsələlərin həllində bulud xidmətlərindən (cloud services) geniş istifadə olunmaqdadır. Bulud xidmətləri İnternet xidmətləri olub, insanlara malik olduqları istənilən informasiyanın emalı və saxlamasını İnternet üzərindən virtual serverlərdə aparmalarını təklif edir [1].

İnormasiya və biliyin virtual serverlərdə saxlaması məsələlərindən danışarkən viki texnologiyaları ilə idarə olunan açıq serverlər də nəzərə alınmalıdır.

Son illər viki texnologiyaların sürətli inkişafı və populyarlaşması virtual məkanda yeni-yeni layihələrin yaranmasına və bu layihələrin q1sa zamanda həddən artıq çox informasiya ilə zənginləşdirilməsinə səbəb olmuşdur. Viki texnologiyaları ilə idarə olunan İnternet-layihələrin q1sa müddət ərzində böyük həcmli informasiyaya malik olması və populyarlaşmalarının əsas səbəbləri açıq olmaları və kontentlərin daxil edilməsi üsullarının sadəliyidir. Vikilayihələrin verdiyi imkanlar istənilən İnternet istifadəçisinin veb-səhifələrin yaradılması prosesində aktiv iştirakına şərait yaradir $[2,3]$.

Tədqiqatın əsas məqsədi viki texnologiyaları ilə bulud xidmətlərinin fərqli və oxşar cəhətlərini müəyyənləşdirmək, bulud xidmətlərinin xüsusiyyətlərini analiz etmək və viki texnologiyalarından istifadə etməklə məlumatların buludda saxlaması imkanlarından səmərəli istifadə edilməsi məsələlərinin üstünlüklərini müəyyənləşdirməkdir.

\section{BULUD XIDMӘTLӘRİ}

Bulud xidməti dedikdə İnternetdən istifadə etməklə xarici hesablama resurslarından dinamik, ohatəli istifadə xidməti nəzərdə tutulur. Burada istifadəçiyə buludun infrastrukturu və bulud serverlərinin necə idarə olunması haqqında biliyə malik olması vacib deyil. Bulud xidmotlərində buludun hans1 proqram təminatı ilə işləməsi və buludda daha hansı resursların və necə saxlanıldığı istifadəçini maraqlandırmır. Onu yalnız bir məsələ maraqlandırır: buluda göndərilən sorğu əsasında məsələnin həlli və nəticənin əlyetərliyi. Bulud modeli daxili və xarici hissələrdən ibarət iki elementin İnternet üzərindən birləşməsini nəzərdə tutan şəbəkədir. Modelin daxili hissəsini bulud təşkil edir. Daxili hissədə bulud xidmətlərini həyata keçirən proqram təminatları, kompüterlər, serverlər və verilənlər bazası yerləşir. Xarici hissəsi isə istifadəçinin buludla əlaqəsidir. Bulud xidmətlərinin xarici hissəsini bulud xidmətlərindən istifadə üçün nəzərdə tutulmuş kliyent kompüter və ya şirkətin kompüterlər şəbəkəsi təşkil edir.

Bulud İnternet deyil və bulud xidmətləri dedikdə onun bir seqmenti olan, kliyent sorğusunu emal edən proqram və aparat təminat1 toplusundan ibarət xidmətlər nəzərdə tutulur. Hər hansı saytın brauzerə gətirilməsi, e-poçt xidməti və İnternetin digər xidmətləri özlüyündə bulud texnologiyaların ən sadə tərəfidir. İnternetin yaranma tarixinə nəzər salsaq görərik ki, bu qlobal şəbəkənin yaradılmasında əsas məqsəd uzaq məsafədən müxtəlif hesablama sistemlərinə əlyetərliyi təmin etmək olmuşdur ki, bu proses özü də bulud xidmətlərini xatırladır.

Bulud texnologiyaların sürətli inkişafını şərtləndirən əsas səbəb iqtisadi cəhətdən əlverişli olması, əlyetərliyi, istifadə üçün rahatlığıdır. İstifadəçilərin bulud xidmətlərdən istifadə edə bilməsi üçün xidmət göstərən tərəfin icazəsi olmalıdır. İcazə abunə yazısı və ya icarə hüququ əsasında verilir [4]. Bulud xidmətləri tətbiq sahəsindən asılı olaraq müxtəlif olurlar: hamı üçün əlyetərli olan ictimai bulud xidmətləri (public cloud), xüsusi bulud xidmotləri (private cloud), korporativ bulud xidmətləri (community cloud), hibrid bulud xidmətləri (hybrid cloud) və s. İctimai bulud xidmətləri nəhəng şirkətlər tərəfindən İnternet istifadəçilərinə təklif edilir. Xüsusi bulud xidmətləri isə bir təşkilat tərəfindən öz işçiləri üçün təklif olunur. Korporativ bulud birgə fəaliyyət üçün nəzərdə tutulur. Digər bulud xidmətlərindən birgə istifadə xidməti hibrid bulud adlanır $[1,4]$.

İctimai bulud xidmətləri konsepsiyası resursların toplanması, emalı və saxlamasında kənar virtual serverlərin xidmətindən istifadəni nəzərdə tutur. $\mathrm{Bu}$ xüsusiyyət 
informasiya təhlükəsizliyi və müəlliflik hüquqlarının qorunması baxımından müəyyən problemlər yaradır. Belə ki, bu zaman proqramın realizə detalları çox hallarda naməlumdur və istifadəçi öz işində istifadə etdiyi proqram platformasını tam idarə etmir. Müəyyən müddətdən sonra idarə edilməyən verilənlərin çoxalması problemi yaranır.

Müasir şəraitdə yeni məhsulu və ya xidməti bazara çevik şəkildə ç1xartmaq üçün informasiya sistemlərini genişləndirmək, yaxud modifikasiya etmək zərurəti yaranır. Onənəvi olaraq, informasiya sistemlərində dəyişikliklərin aparılması üçün əvvəlcədən avadanlığın seçilməsi, alınması və quraşdırılması ilə bağlı məsələlər həll edilirdi. Bu işlər müəyyən vaxt tələb edirdi. Bulud xidmətləri tələb olunan resursların istifadəçi tərəfindən bir neçə dəqiqə ərzində əldə edilməsinə imkan verir. Mütəxəssislərin fikrinə görə gələcəkdə bulud xidmətləri sosial-iqtisadi münasibətlərin müxtəlif sahələrini əhatə edərək, informasiya və biliklər cəmiyyətinin əsas faktoru olacaqdır. Mütəxəssislər hesab edirlər ki, 2020-ci ildə dünyadakı elektron informasiyanın üçdə biri buludlarda saxlanılacaq və emal olunacaqdır. Bulud xidmətlərindən əldə olunacaq orta illik gəlir isə $20 \%$ təşkil edəcəkdir $[4,5]$.

Bulud texnologiyaların təsviri modeli çərçivəsində bulud xidmətlərinə proqram təminatı xidməti (Software-as-aService), təhlükəsizlik xidməti (Security-as-a-Service, verilənlər bazası xidməti (Database-as-a-Service), informasiyanın saxlaması xidməti (Storage-as-a-Service), prosesin idarəedilməsi xidməti (Process-as-a-Service), informasiya xidmoti (Information-as-a-Service), platforma xidməti (Platform-as-a-Service), inteqrasiya xidməti (Integration-as-a-Service), infrastruktur xidməti (Infrastructure-as-a-Service), menecment/idarəetmə xidməti (Management/Governace-as-a-Service) və s. xidmətlər daxildir [5].

Bulud xidmətləri texniki deyil, daha çox kommersiya xarakterli olsa da, burada məhz proqramçıların yenilik etmələri üçün daha böyük imkanlar vardır. Belə ki, bulud xidmətləri keçmişdə böyük vaxt aparan və problemlər yaradan bir çox yorucu işlərdən qurtulmağa imkan verir. Məsələn, hər bir proqramçı bilir ki, proqram təminatını təcrübə laboratoriyasından istehsala keçirmək üçün nə qədər çətinlikləri dəf etmək lazım gəlir. Bulud xidmətləri şəraitində isə virtual maşınların konfiqurasiyasının işlənib hazırlanması və istehsal prosesində tətbiqi üçün eyni bulud xidmətindən istifadə edilir. $\mathrm{Bu}$ isə aparat və proqram təminatlarındakı fərqliliklərlə bağlı yaranan problemlərdən qaçmağa imkan verir. Belə bir şəraitdə proqramçılar bütün diqqətlərini yaradıcılıq məsələlərinə yönəldə bilirlər. Nəticədə daha az müddətdə və daha az resurslar hesabına verilənlərin buludda itkisiz saxlanmasına, daha məhsuldar və səmərəli işləməyə imkan yaranır.

Məsələn, platforma xidməti (PaaS) istifadəçilərə bulud infrastrukturunda əməliyyat sistemi yüklənmiş platforma, proqram təminatı və orada müxtəlif tətbiqi məsələlərin həllini həyata keçirmək üçün imkanlar verir. Oməliyyat sistemi kimi Unix, Ubuntu Server, BSD/OS Family, Solaris/SunOS, Windows Server və s. proqram paketlərindən, verilənlər bazasının idarəetmə sistemi kimi MySQL, Microsoft SQL,
SQL Database, PostgreSQL, Oracle və s. proqramlardan istifadə etmək mümkündür. Veb-səhifələrin yaradılması üçün Python, Java, PHP, Ruby, CGI-skriptlər, Perl, JS və $\mathrm{s}$. proqramlaşdırma dillərindən istifadə olunur. Göründüyü kimi, PaaS proqramçıları hər hansl proqram təminatı üzərində işləmək üçün lazım olan vasitələrlə təmin etmək imkanına malikdir.

Bir çox bulud xidmətlərində istifadəçi yalnız serverin fiziki istifadə etdiyi hissəsi üçün pul ödəyir. $O$, serverin texniki xidmətləri, proqram təminatı və s. xərclərdən azaddır. Bulud xidmətlərində istifadə edilən resurslara görə ödənişin bir hissəsini əməliyyat xərclərinə yönəltmək mümkündür. Bulud xidmətləri müxtəlif istifadəçi qruplara, təşkilatlara və istifadəçi kateqoriyalarına və s. xidmət göstərmək üçün ümumi resurslardan maksimum istifadə hesabına xərclərin azaldılması üstünlüklərinə malikdir. Multi-icarə (multitenancy) adlanan bu xüsusiyyət proqram təminatı yaradan şirkətlər üçün daha cəlbedici ola bilər. Çünki bu üsul bulud platforması resurslarına ödəniş etmək üçün nəzərdə tutulan xərclərə qənaət etməyə və əlyetərli hesablama resurslarından maksimum dərəcədə faydalanmağa imkan yaradır [6]

Multi-icarə arxitekturasında proqram əlavələri buludlarda saxlanılan məlumatlar üzərində müxtəlif əməliyyatların aparılmasına şərait yaradır. Məsələn, proqram əlavələri eyni vaxtda buraxılan nüsxələrin sayının artması hesabına böyük həcmdə verilənlərə davam gətirməyə imkan verir. Məlum olduğu kimi, çoxlu sayda nüsxələrin eyni zamanda buraxılmasında tipik avadanlıqdan istifadə edilir ki, bu da müvafiq xərclərin ümumi dəyərini aşağı salır və infrastrukturun müşayiət edilməsini asanlaşdırır. Multi-icarə arxitekturasında hər bir icarəçinin proqramda payı vardır və icarəçinin məkanı əvvəlcədən müəyyən olunmuş resurslar fəzasını təşkil edir. Multi-icarə platformalarına misal olaraq IaaS və PaaS xidmətlərini göstərmək olar [7].

Multi-icarə təklif olunan proqram təminatından birgə istifadədir və bu da viki konsepsiyasının əsas prinsipi ilə üstüstə düşür. Virtual məkanın ən populyar viki-layihələrindən olan Wikipedia, Wikimedia Commons, Wikitravel, LyricWiki, TermWiki, WikiTree, WikiMapia və digərlərinin imkanları və böyük həcmləri (milyonlarla viki-səhifələrə malik) onları bulud saxlamaları ilo bir siraya qoyur. Viki texnologiyalarından virtual ensiklopediyalar, sorğu sistemləri, şəxsi bloqlar və sosial şəbəkələrin yaradılmasında geniş istifadə olunur. Viki texnologiyaları yalnız motn tipli informasiya ilə deyil, eyni zamanda elektron cədvəllər, təqvimlər, şəkil qalereyaları, video və audio-fayllarla işləməyə imkan yaradır. Başqa sözlə viki texnologiyalar multi-icarə təklif edən layihələrin hazırlanması üçün vasitədir.

Bu gün viki-layihələr yaratmaq üçün müxtəlif proqram platformalarında tortib olunmuş viki-aparatlardan istifadə edilir. Proqram platformaları şəbəkə istifadəçilərinin birbaşa brauzerdən veb-səhifələrlə və VB ilə əlqəli işini təmin edir. Viki-aparatlar yaratmaq üçün əsasən CGI-skriptlər, Perl, PHP, JSP, ASP, Python, Tcl, Small Talk və s. proqram platformalarından istifado olunur. Viki-aparatlara misal olaraq DidiWiki, DokuWiki, FlexWiki, MediaWiki, PmWiki və s. proqram təminatlarını göstərmək olar [3]. 


\section{BULUD SAXLAMALARININ ÜSTÜNLÜKLӘRİ}

Bulud saxlaması (cloud storage) dedikdə informasiyanın virtual məkanda paylanmış çoxsaylı serverlərdə saxlaması nəzərdə tutulur. Bulud saxlaması bulud xidmətlərinə aiddir və burada informasiyanın saxlaması və təhlükəsizliyi məsələləri şəxsi serverlərdə informasiyanın saxlaması modelindən fərqli olaraq qeyri-şəffafdır. Belə ki, bulud xidməti göstərən serverlərin harada yerləşməsi, daxili strukturu və sayı məlum olmur. 2012-ci ildən etibarən bulud təkliflərinin kütləvi yayılması prosesinin başlanmasına baxmayaraq $[2,6]$ bulud xidmətlərinin qeyri-şəffaflığ 1 bu xidmətlərdən istifadənin geniş vüsət almasına mane olmaqdadır. Lakin buna baxmayaraq bulud saxlamalarının təklif etdiyi xidmətlər informasiyanın durmadan artdığı və dəyişdiyi bir dövrdə çox əhəmiyyətlidir. Bulud saxlamasının əsas üstünlükləri aşağıdakılardır:

- Məlumatın İnternet şəbəkəsinə qoşulmuş istənilən kompüterdən əldə edilə bilməsi;

- Təşkilatların və ya bir təşkilat əməkdaşlarının eyni informasiya ilə birgə işləmək imkanı;

- Verilənlərin buludda, böyük ehtimalla itkisiz saxlaması;

- Verilənlərin saxlaması və emalı prosesinin ucuz başa gəlməsi.

İT bazarının tədqiqi ilə məşğul olan ABŞ-ın məşhur "International Data Corporation" (IDC) şirkətinin vitseprezidenti Frank Gens bildirir ki, şirkətlor bulud texnologiyalarını yalnız iqtisadi üstünlüklərinə görə deyil, həm də rahatlığına görə həvəslə tətbiq edirlər. Məsələn, tutaq ki, şirkətin yeni pilot layihəsinin reallaşdırılması üçün bir neçə yeni serveri istismara vermək tələb olunur. Ovvəllər bunun üçün avadanlıq almaq və onu data-mərkəzdə yerləşdirmək lazım gəlirdi ki, bunun üçün də həftələlərlə, aylarla vaxt tələb olunurdu. Bulud xidmətlərindən istifadə zamanı isə, sadəcə, zəruri sayda virtual serverləri aktivləşdirmək və işə başlamaq lazımdır [8].

Bulud texnologiyaların meydana gəlməsinə qədər böyük həcmli verilənlərin saxlaması və emalı üçün baha başa gələn informasiya sistemlərindən istifadə etmək lazım gəlirdi. Bu isə yalnız nəhəng şirkətlər üçün əlyetərli idi. Lakin bulud texnologiyaların yaranması ilə hətta kiçik şirkətlər də böyük həcmli verilənlər üçün hesablama məsələlərini həll etmək imkanı qazandılar. Olbəttə, korporativ veb-saytlarla bağlı perspektivlər o qədər də əhəmiyyətli deyil, amma söhbət böyük verilənlər massivinin emalını tələb edən biznesanalitika sistemlərindən gedirsə, bulud texnologiyaların kommersiya perspektivləri daha ciddi qəbul edilməlidir.

Microsoft, Google, IBM və Amazon kimi nəhəng şirkətlər istifadəçilərin işlərini daha da rahat etmək üçün bulud saxlamaları təklif edirlər. Bulud saxlamalarına misal olaraq Google Drive, Dropbox, Microsoft OneDrive, iCloud va s. kimi sistemləri nümumə göstərmək olar. Məsələn, Dropbox bulud saxlaması şoxsi faylların saxlandığı virtual bazadır. Sistem istifadəçiyə informasiyasını saxlamaq üçün $2 \mathrm{Qb}$ yer ayırır. Sistemə qoşulan zaman istifadəçinin kompüterində avtomatik olaraq xüsusi qovluq yaradılır və İnternetə girişdə qovluqdakı işlər bulud serveri ilə avtomatik sinxronlaşdlrılır.
$\mathrm{Bu}$ sistemin əsas üstünlüyü fayl üzərində edilən bütün dəyişikliklərin tarixçəsinin saxlaması və silinmiş və ya dəyişdirilmiş faylı əvvəlki vəziyyətinə bərpa etmək imkanının olmasidir [9].

Silinmiş və ya dəyişdirilmiş faylın əvvəlki vəziyyətinə bərpa edilməsi imkanı viki-layihələrdə də vardır. Viki-mühit istifadəçiyə şəxsi və müzakirə səhifələrinə malik olmaq, vebsəhifələrdə dəyişikliklər etmək və istənilən sayda yeni vebsəhifə yaratmaq imkanları verir ki, bu xüsusiyyətlər onu bulud saxlamasına bənzədir.

\section{BULUD SAXLAMALARININ ÇATIŞMAZLIQLARI}

Bulud saxlamaları da daxil olmaqla bulud xidmətlərinin üstünlükləri ilə yanaşı, müəyyən çatışmamazlıqları da mövcuddur. $\mathrm{Bu}$ çatışmamazlıqlar ilk növbədə, bulud xidmətlərinin informasiya təhlükəsizliyi və hüquqi tənzimlənmə məsələləri ilə bağlidır. Məsələn, provayder müştərinin buludda saxladığı verilənlərə baxa bilir. Həmçinin, verilənlərin xakerlərin əlinə keçməsi ehtimalı da mövcuddur. Deyilənləri nəzərə alaraq bulud saxlamalarında yarana biləcək neqativ halları aşağıdakı kimi təsnifatlandırmaq olar:

- Bulud texnologiyalar İnternetdən asılıdır. İnternetə giriş kəsilirsə buludla əlaqə kəsilir;

- Buludun sahibi var. Bulud xidmətləri göstərən provayderin istifadəçinin şəxsi məlumatlarına müdaxiləsi ehtimalı böyükdür;

- Bulud xidmətlərinin əksəriyyəti pulludur və ödəmə vaxtında edilmədikdə buludda saxlanılan sənədlərin itirilməsi problemi mövcuddur.

Təsnifatlandırmanın ilk iki bəndi viki-layihələr üçün də xarakterikdir. Belə ki, viki texnologiyaları müasir İnternet texnologiyalarına aiddir, digər tərəfdən viki-layihələrin də administratorları var və onlar lazım bildikləri an vikiistifadəçinin fəaliyyətini məhdudlaşdıra, şəxsi səhifəsini silə bilərlər.

Cədvəl 1-də bulud xidmətləri ilə viki-layihələrin əsas xüsusiyyətləri müqayisə olunmuşdur. Cədvəldən göründüyü kimi həm buludların, həm də viki-layihələrin təklif etdiyi xidmətlərin çox hissəsi xüsusiyyətlərinə görə eynidir və əsasən istifadəçilərin İnternet şəbəkəsində fəaliyyətlərinin səmərəliliyinə və böyük həcmli verilənlərin etibarlı saxlamasina xidmət edir.

$\mathrm{Bu}$ xidmətlər həmçinin, verilənlərin əlyetərliyi və emalı məsələlərinin həllində optimallığın əldə olunması üçün nəzərdə tutulmuşdur. Müqayisəli analiz hər iki konsepsiya arasında müəyyən fərqin olduğunu da müəyyən etmişdir ki, bunlar da aşağıdakılardır:

- Viki-layihələrdə saxlanılan məlumatlar kütləvi istifadə üçün nəzərdə tutulmuşdursa, buludda saxlanılan informasiya istifadəçinin şəxsi məlumatı sayılır və onun icazəsi olmadan kütləviləşə bilməz; 
CəDVӘL 1. BULUD XIDMӘTLӘRİ İLə VIKİ-LAYIHHLӘRIN MÜQAYİSəSİ

\begin{tabular}{|c|c|c|}
\hline Xüsusiyyəti & Bulud & Viki \\
\hline Xidmət xərci & $\begin{array}{l}\text { Yeni aparat və proqram } \\
\text { təminatına ödəniş etmədən } \\
\text { və ya qismən ödəniş } \\
\text { etməklə buluddan istifadə. }\end{array}$ & $\begin{array}{l}\text { Yeni aparat və proqram } \\
\text { təminatına ödəniş edilmir, } \\
\text { bütün xidmətlər pulsuzdur. }\end{array}$ \\
\hline $\begin{array}{l}\text { Səmərəliliyin } \\
\text { yüksəldilməsi } \\
\text { imkanları }\end{array}$ & $\begin{array}{l}\text { Xidmətlər üçün nəzərdə } \\
\text { tutulmuş proqram təminatı } \\
\text { başqa məqsədlər üçün } \\
\text { istifadə oluna və ya } \\
\text { dəyişdirilə bilərlər. }\end{array}$ & $\begin{array}{l}\text { Xidmətlər üçün nəzərdə } \\
\text { tutulmuş proqram təminatı } \\
\text { başqa məqsədlər üçün } \\
\text { istifadə oluna bilər, lakin } \\
\text { dəyişdirilə bilməzlər. }\end{array}$ \\
\hline $\begin{array}{l}\text { Veb üçün } \\
\text { proqram } \\
\text { platformalar1 }\end{array}$ & $\begin{array}{l}\text { Python, Java, PHP, Ruby, } \\
\text { CGI-skriptlər, Perl, JS və s. }\end{array}$ & $\begin{array}{l}\text { CGI-skriptlər, Perl, PHP, } \\
\text { JSP, ASP, Python, Tcl, } \\
\text { Small Talk və s. }\end{array}$ \\
\hline $\begin{array}{l}\text { Tətbiq } \\
\text { müxtəlifliyi }\end{array}$ & $\begin{array}{l}\text { Tətbiq sahəsinə görə } \\
\text { buludlar ictimai və xüsusi } \\
\text { buludlara bölünürlər. }\end{array}$ & $\begin{array}{l}\text { Viki-layihələrin əksəriyyəti } \\
\text { ictimaidir. Şirkət daxili } \\
\text { xüsusi viki-layihələr də } \\
\text { mövcuddur. }\end{array}$ \\
\hline İnternet & $\begin{array}{l}\text { İnternet şəbəkəsindən } \\
\text { istifadə tələb olunur }\end{array}$ & $\begin{array}{l}\text { İnternet şəbəkəsindən } \\
\text { istifadə tələb olunur }\end{array}$ \\
\hline Genişlənmə & $\begin{array}{l}\text { Böyük həcmli verilənlərlə } \\
\text { işləməyə imkan verir. }\end{array}$ & $\begin{array}{l}\text { Böyük həcmli verilənlərlə } \\
\text { işləmək mümkündür. }\end{array}$ \\
\hline Elastiklik & $\begin{array}{l}\text { İş prosesində yaranan } \\
\text { situasiyalara uyğun olaraq } \\
\text { informasiya sistemində } \\
\text { prosesi dəyişmək } \\
\text { mümkündür. }\end{array}$ & $\begin{array}{l}\text { İş prosesində yaranan } \\
\text { situasiyalara uyğun olaraq } \\
\text { informasiya sistemində } \\
\text { prosesi dəyişmək mümkün } \\
\text { olmasa da, alternativ } \\
\text { resurslar yaratmaq olar. }\end{array}$ \\
\hline Olyetətlilik & $\begin{array}{l}\text { Saxlanılan informasiyanın } \\
\text { formatı və tipi nəzərə } \\
\text { alınmır. Çevik və etibarlı } \\
\text { fəaliyyət sifarişçilərin } \\
\text { tələblərinə cavab verir. }\end{array}$ & $\begin{array}{l}\text { İstənilən formatda və tipdə } \\
\text { informasiya daxil edilməyə } \\
\text { icazə verilir. Dəyişdirilən } \\
\text { və ya silinən informasiyanı } \\
\text { bərpa etmək mümkündür. }\end{array}$ \\
\hline $\begin{array}{l}\text { Zaman } \\
\text { itkisinin } \\
\text { minimuma } \\
\text { çatdırılması }\end{array}$ & $\begin{array}{l}\text { Buludlarda zaman itkisi } \\
\text { yalnız zəruri sayda virtual } \\
\text { serverləri aktivləşdirmək } \\
\text { və işə başlamağa sərf } \\
\text { edilir. }\end{array}$ & $\begin{array}{l}\text { Viki-mühitdə zaman itkisi } \\
\text { yalnız dilin və şablonların } \\
\text { seçilməsinə sərf edilir. }\end{array}$ \\
\hline Kütləvilik & $\begin{array}{l}\text { Bulud xidmətləri böyük } \\
\text { həcmli informasiya } \\
\text { massivlərinin emalının } \\
\text { kollektiv aparılmasına } \\
\text { imkan yaradır. Resurlar } \\
\text { istifadəçilər tərəfindən } \\
\text { qeyri-bərabər istifadə } \\
\text { olunur. }\end{array}$ & $\begin{array}{l}\text { Kollektiv şəkildə } \\
\text { informasiya yaratmaq və } \\
\text { emal etmək üçün nəzərdə } \\
\text { tutulmuşdur. Yaradılan veb- } \\
\text { səhifələr tutumuna və } \\
\text { keyfiyyətinə görə } \\
\text { fərqlənirlər. }\end{array}$ \\
\hline
\end{tabular}

- Viki-mühit həm də sosial şəbəkədir və istifadəçi tərəfindən daxil edilən məlumat haqqında başqaları rəy bildirə bilər. Bulud saxlamaları sosial şəbəkə deyil və başqaları buludda saxlanılan informasiyaya münasibət bildirə bilməz;

- Viki-mühitdə saxlanılan məlumatlar ümumi istifadə üçün nəzərdə tutulmuşdur və onların layihədə qalıbqalmamasina administratorlar qərar verirlər. Buludda saxlanılan informasiya isə yalnız bu informasiyanı daxil edən istifadəçi və ya istifadəçi qrupuna məxsusdur.

\section{NӘTİCə}

Viki-layihələr də bulud xidmətləri kimi müxtəlif tipli informasiya resurslarının elektron formada virtual serverlərdə saxlaması və emalı üçün nəzərdə tutulmuşlar. Viki-mühitin və bulud xidmətlərinin xüsusiyyətlərini müqayisə edərkən məlum oldu ki, hər iki konsepsiya informasiyanın daha etibarlı saxlamas1, əlyetərli olması, xidmətlərdə kiçik xərc tələb etməsi və operativ şəkildə dəyişdirilməsinə imkan yaratdı̆̆ına görə oxşardırlar və istifadəçilərin informasiya ilə işlərkən daha rahat üsullardan və az zamandan istifadəsini nəzərdə tuturlar.

Virtual şəbəkə resurslarından və İnternet xidmətlərindən səmərəli istifadə ölkədə elektron dövlətin inkişafı və biliklər cəmiyyətinin formalaşmasında mühüm amildir. Bu gün hər saniyə artmaqda olan böyük həcmli verilənlər buludlarda, elektron kitabxanalarda, virtual ensiklopediyalarda, sosial şəbəkələrdə və müxtəlif informasiya sistemlərində saxlanılır. $\mathrm{Bu}$ imkanlar böyük həcmli verilənlərlə bağlı meydana çıxan problemlərin qismən həll olunmasına şərait yaradır.

\section{ӘDӘВIYYAT}

[1] R.M.Oliquliyev, F.C.Abdullayeva. "Bulud texnologiyalarının təhlükəsizlik problemlərinin tədqiqi və analizi", İnformasiya texnologiyalar problemləri, 2013, №1, səh. 3-14.

[2] J.Moskaliuk, J.Kimmerle, U.Cress,. "Collaborative knowledge building with wikis: The impact of redundancy and polarity", Journal of Computers \& Education, 2012, vol. 58, No. 4, pp. 1049-1057.

[3] R.M.Alguliyev, R.M.Aliguliyev, I.Y.Alakbarova, "Extraction of hidden social networks from wiki-environment involved in information conflict", International Journal of Intelligent Systems and Applications (IJISA), 2016, vol. 8, no.2, pp. 20-27.

[4] R.Ş. Mahmudov, "Bulud texnologiyalari iqtisadiyyatinin mövcud vəziyyəti və inkişaf perspektivlərinin analizi”, İnformasiya cəmiyyəti problemləri, 2014, №2, səh.14-23.

[5] R.Q.Đləkbərov, M.A.Həşimov, "Bulud texnologiyalari: xidmətlər, problemlər və tətbiq sahələri”, İnformasiya texnologiyaları problemləri, 2016, №1, səh. 3-10.

[6] C.P.Bezemer, A.Zaidman, "Multi-tenant saas applications: maintenance dream or nightmare?", Proceedings of the Joint ERCIM Workshop on Software Evolution and International Workshop on Principles of Software Evolution, 2010, NY, ACM, pp. 88-92.

[7] R.Krebs, C.Momm., S.Kounev, "Architectural Concerns in Multi-tenant SaaS Applications",/ Proceedings of the 2nd International Conference on Cloud Computing and Services Science, 2012, p. 426-431.

[8] "IDC FutureScape: Worldwide Cloud 2016 Predictionsg", 2016, 22 p., www.cofinaeventos.pt/

[9] https://www.dropbox.com/ 